\title{
Effects of biofertilizer rates on the structural, morphogenetic and productive characteristics of Piatã grass
}

\section{Marco Antonio Previdelli Orrico Junior ${ }^{1}$, Stanley Ribeiro Centurion ${ }^{2}$, Ana Carolina Amorim Orrico $^{3}$, Natália da Silva Sunada ${ }^{4}$}

\footnotetext{
${ }^{1}$ Doutorando do Programa de Pós-Graduação em Zootecnia, Universidade Estadual Paulista "Júlio de Mesquista Filho".

2 Granduando do curso de Zootecnia, Universidade Federal da Grande Dourados.

${ }^{3}$ Curso de Zootecnia da Faculdade de Ciências Agrárias, Universidade Federal da Grande Dourados.

${ }^{4}$ Mestranda do Programa de Pós-Graduação em Zootecnia, Universidade Federal da Grande Dourados.
}

ABSTRACT - The objective of this study was to investigate the influence of different levels of biofertilizers from cattle and swine manure on the structural, morphogenetic and productive characteristics of Brachiaria brizantha cv. Piatã. The experiment was arranged in a completely randomized factorial design with split plots. The plots were defined by eight treatments: two biofertilizers (cattle and swine), four levels (0, 100, 200 and $300 \mathrm{~kg} \mathrm{~N} . \mathrm{ha}^{-1}$ ) and subplots by four different cutting periods. The cutting for plant uniformity was performed at 45 days after sowing at $15 \mathrm{~cm}$ above the soil surface. The biofertilizeres were applied in a single level, after the cutting of plants, in rates of $0,0.23$ and $0.19,0.45$ and 0.38 , 0.68 and 0.57 liters pot ${ }^{-1}$ for the biofertilizers from cattle and swine manure, respectively. These rates were also equivalent to levels of $0,100,200$ and $300 \mathrm{~kg} \mathrm{~N} \cdot \mathrm{ha}^{-1}$. There was no significant difference between the types of biofertilizers as there was no interaction between them and the different levels, hence both biofertilizers could be applied without any loss of nutrient intake by the plants used in this experiment. There was a significant difference between the production of green and dry matter, the leaf appearance rate, phyllochron, leaf and pseudostem elongation rates, number of green leaves, final leaf length, number and weight of tillers, according to the increase of nitrogen rates, following linear prediction model. Effect of the cutting periods was also observed, once the plants harvested during the summer presented greater performance of structural and morphogenetic characteristics.

Key Words: Brachiaria brizantha, forage production, organic fertilizer, phyllochron

\section{Introduction}

Pig and cattle rearing are characterized as farming activities that may cause serious environmental damage, especially when the waste produced from these animal facilities is not managed properly. Based on this scenario, the anaerobic digestion has become one of the most widely used processes in the treatment and recycling of waste generated from animal production, mainly due to stabilization of organic matter, reducing or eliminating pathogens and adding value to these activities with the production of biogas and biofertilizer.

Despite the efficiency of the process, the anaerobic digestion does not solve the waste problem completely, but it just reduces the organic load, leaving a high amount of minerals, which prevents its indiscriminate discharge on soil or on water bodies. In order to resolve this issue, several farming productions follow a system in which the animal production and grain or pasture production are integrated. Thus, most of the nutrients present in the manure can be used by the crop and exported from these areas after the harvest, decreasing the chances of soil saturation and consequent contamination of groundwater (Oliveira, 2006).

Since part of the nutrients in manure is not fully mineralized (available for plants), this prevents its total immediate consumption by the plants which, in turn, provide a slower growth when compared with mineral fertilization. However, when the manure undergoes the anaerobic fermentation process, most of the organic matter is degraded, releasing the nutrients that were unavailable before. An example was reported by Silva et al. (2006) while evaluating the Brachiaria decumbens Stapf pasture with conventional mineral fertilization and the fertilization with effluent from stabilization lagoon of swine waste, in which the authors did not observe significant differences in the levels of leaf absorption of nitrogen, phosphorus and potassium.

Although the effluents from animal operations can be used as fertilizers, the understanding of some relations, such as plant growth with different types and rates of effluents is not clear. Based on this assumption, the objective of this study was to assess the influence of different rates of biofertilizers produced from cattle and swine manure on 
the structural, morphogenetic and productive traits of Brachiaria brizantha cv. Piatã.

\section{Material and Methods}

The experiment was carried out at the experimental greenhouse unit from the College of Agriculture Sciences of Universidade Federal de Grande Dourados, UFGD, located at Dourados county, MS, Brazil at $22^{\circ} 13^{\prime} 16^{\prime \prime S}$ latitude and $54^{\circ} 17^{\prime} 01^{\prime \prime} \mathrm{W}$ longitude and altitude of $430 \mathrm{~m}$. According to the Köppen climate classification, the climate of the region is humid mesothermal - Cwa, presenting average temperature and precipitation between 20 and $24^{\circ} \mathrm{C}$ and 1250 and $1500 \mathrm{~mm}$, respectively (Table 1 ).

The experiment was performed in a completely randomized factorial design with split plots. The plots were defined by eight treatments: two types of biofertilizers (manure from cattle and swine), four rates of biofertilizers

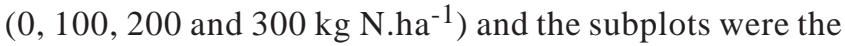
four cutting periods. Each one of the treatments had six repetitions (plant pot), totaling 48 plastic plant pots with capacity of $9 \mathrm{dm}^{3}$ of soil. The pots were also sealed to prevent leaching of soil mineral.

The soil used on this experiment was classified as red dystrophic latosoil - Hapludox, according to Embrapa (1999) and presented the following characteristics: $\mathrm{pHCaCl}_{2}=4.3$; P in resin $=0 \mathrm{mg} . \mathrm{dm}^{-3} ; \mathrm{K}=0.3 \mathrm{mmol} . \mathrm{dm}^{-3} ; \mathrm{Ca}=4.0 \mathrm{mmol}^{-\mathrm{dm}^{-3}}$; $\mathrm{Mg}=3.0 \mathrm{mmol} . \mathrm{dm}^{-3} ; \mathrm{Al}+\mathrm{H}=94.0 \mathrm{mmol} . \mathrm{dm}^{-3} ;$ sum of bases $=$ $7.3 \mathrm{mmol} . \mathrm{dm}^{-3}$; cations exchange capacity $=101.3 \mathrm{mmol} . \mathrm{dm}^{-3}$; bases saturation $=7.2 \%$; organic matter $=47.1 \mathrm{~g} \cdot \mathrm{dm}^{-3}$; sand $=$ $12.0 \%$; silt $=72.7 \%$ and clay $=15.3 \%$.

After the results of chemical analysis of soil, liming was performed 60 days before sowing in order to increase the base saturation to $50 \%$, through application of $1.96 \mathrm{~g} . \mathrm{dm}^{-3}$ of Filer limestone. Due to low soil fertility, the fertilization was performed in order to ensure the forage grass growth. $204 \mathrm{mg} . \mathrm{dm}^{-3}$ of N, $818 \mathrm{mg} \cdot \mathrm{dm}^{-3}$ of $\mathrm{P}_{2} \mathrm{O}_{5}$ and $187 \mathrm{mg} \cdot \mathrm{dm}^{-3}$ $\mathrm{K}_{2} \mathrm{O}$ were applied as urea, simple superphosphate and potassium chloride, respectively. The plants were watered with distilled water in order to prevent the influence of

Table 1 - Meteorological data collected in the greenhouse during the experimental period

\begin{tabular}{|c|c|c|c|c|}
\hline \multirow[t]{2}{*}{ Month/2010 } & $\operatorname{maxT}$ & $\operatorname{minT}$ & $\operatorname{avgT}$ & \multirow{2}{*}{$\begin{array}{c}\text { avgRH } \\
\%\end{array}$} \\
\hline & \multicolumn{3}{|c|}{${ }^{\circ} \mathrm{C}$} & \\
\hline January & 30.9 & 20.9 & 24.9 & 83.1 \\
\hline February & 32.2 & 21.8 & 25.9 & 78.7 \\
\hline March & 32.8 & 20.0 & 25.6 & 70.3 \\
\hline April & 29.0 & 17.7 & 22.8 & 71.7 \\
\hline May & 23.7 & 12.6 & 17.8 & 79.5 \\
\hline
\end{tabular}

mineral content from tap water. The pots moisture was monitored and controlled every three days, weighing the pots and keeping it about $70 \%$ of the soil field capacity.

Planting took place on January 02, 2010. Ten seeds of Brachiaria brizantha cv. Piatã per pot were sowed and seven days after the emergence period, the plants were thinned out and only three were left per pot. Cutting the plants for uniformity was performed at 45 days after the sowing (February 17, 2010) at $15 \mathrm{~cm}$ above soil surface. Since this date, the experimental period started through the application in a single level of $0,0.23$ and $0.19,0.45$ and $0.38,0.68$ and 0.57 litres.pot $^{-1}$ of biofertilizers of cattle and swine manure, respectively. These rates were also equivalent to levels of 0, 100, 200 and $300 \mathrm{~kg} \mathrm{~N} \cdot \mathrm{ha}^{-1}$. The cattle and swine biofertilizers used in the experiment were produced from semi-continuous biodigesters set up with 30 days of hydraulic retention.

The levels of macrominerals and trace minerals present in the biofertilizers were determined through digestion process performed in a Digesdahl Hach digester using sulfuric acid $\left(\mathrm{H}_{2} \mathrm{SO}_{4}\right)$ and hydrogen peroxide $\left(\mathrm{H}_{2} \mathrm{O}_{2}\right)$ at $50 \%$ (Table 2). Once the digestate solution was produced, the levels of N, P, Ca, Mg, K, Na, Fe, Zn, Mn and Cu were determined (Apha, 2005). Nitrogen level was evaluated according to methodology reported by Silva \& Queiroz, (2006). Phosphorus levels were assessed by the colorimetric method using spectrophotometer HACH model DR-2000 (Apha, 2005). The concentrations of $\mathrm{Ca}, \mathrm{Mg}, \mathrm{K}, \mathrm{Na}, \mathrm{Fe}, \mathrm{Zn}$, $\mathrm{Mn}$ and $\mathrm{Cu}$ were determined through spectrophotometer with atomic absorption model GBC 932 AA (Apha, 2005).

The structural and morphogenetic characteristics were analyzed using two tillers per pot that were identified with colored wires. The analysis started on the third day after cutting plants for uniformity, and then the measurements were made every three days until the plants achieved the cutting height of $30 \mathrm{~cm}$, and were cut at the height of $15 \mathrm{~cm}$ above ground as recommended by Pedreira et al. (2007).

Table 2 - Levels of macro and trace minerals present in the dry matter (DM) of cattle and swine biofertilizers used in this experiment

\begin{tabular}{ccc}
\hline Nutrients (\% DM) & Cattle & Swine \\
\hline $\mathrm{N}$ & 2.43 & 2.92 \\
$\mathrm{P}$ & 1.21 & 2.03 \\
$\mathrm{~K}$ & 0.90 & 1.39 \\
$\mathrm{Ca}$ & 1.47 & 1.51 \\
$\mathrm{Mg}$ & 0.60 & 0.75 \\
$\mathrm{Na}$ & 0.29 & 0.28 \\
$\mathrm{Fe}$ & 0.15 & 0.12 \\
$\mathrm{Cu}$ & 0.03 & 0.51 \\
$\mathrm{Mn}$ & 0.01 & 0.02 \\
$\mathrm{Zn}$ & 0.03 & 0.11 \\
\hline
\end{tabular}


After the cutting of the plants, other tillers were selected and then, the assessment of the next growth period was started.

In order to determine the structural and morphogenetic characteristics, some features were recorded, such as the leaf tip appearance, the day of ligule exposure, length of pseudostems, length of the leaf blade expanded and expanding, number of leaves per tiller, number of tiller per pot and number of green, dead and senesced leaves and then the following variables were calculated:

The leaf elongation rate (LER, cm.tiller-1. day $^{-1}$ ) was calculated based on the total leaf blade length and number of days; leaf appearance rate (LAR, leaf.tiller ${ }^{-1}$.day ${ }^{-1}$ ) was obtained by the leaves emerging on the tagged tillers divided by the number of the days; the phyllochron corresponds to the inverse of LAR, the number of days for a new leaf to emerge; the pseudostem elongation rate (PSER, cm.tiller ${ }^{-1}$.day ${ }^{-1}$ ) was calculated by the difference between initial and final height (calculated based on the ground level up to the ligule of last expanded leaf of each tiller) and number of the days; the final leaf length (FLL, cm) was calculated by the average of all lengths of the fully expanded leaf blades, from the insertion on the ligule up to leaf apex; number of green leaves (NGL, leaves.tiller-1) was obtained by counting the number of green expanded and expanding leaves on the tagged tillers; leaf live span (LLS, days) was estimated taking into account the time between the leaf tip appearance and first sign of senescence of the leaf blade, so, the time the leaf remains green; number of dead and live tillers (tiller.pot ${ }^{-1}$ ) was determined by counting the number of dead and live tillers in each pot; average weight of the tillers (g.tiller ${ }^{-1}$ ) was calculated by dividing the production of dry matter of shoots by the number of live tillers per pot.

The mass of forage grass produced was measured based on the total weight of the green forage obtained from the pot after each cutting (15 $\mathrm{cm}$ above ground). The harvested material was taken to the laboratory to dry in forced-ventilation oven in order to obtain the level of dry matter (DM) to calculate the production of DM per pot.

The results were submitted to variance analysis and then, the type of biofertilizer, rate, the period of cutting and the interaction between them was considered source of variation and was tested at $1 \%$ of probability. The levelresponse of nitrogen was assessed by regression analysis while the effect of biofertilizer types was compared by the F-test and the effect of different cutting periods was evaluated by the Scott-Knott test at $1 \%$ of probability. The analyses were performed using SAEG (Sistema de Análises Estatísticas e Genéticas, version 8.0.).

\section{Results and Discussion}

As the cutting of the grass at the height of $30 \mathrm{~cm}$ was chosen as a criterion instead of a pre-defined period of time, there were differences in the period in which the treatments were harvested during the whole experiment (Table 3).

Despite the variation between the cutting intervals (Table 3), the senescence of the leaves was not observed in any of the treatments which in turn prevented the estimation of average leaf lifespan. Silveira et al. (2010) evaluated eight types of Brachiaria brizanta cultivars in free growth and reported that the $B$. brizantha $\mathrm{cv}$. Piatã was the one with the longest leaf lifespan (78 days), which explains why the senescence of the leaves was not observed during the experimental period.

The type of biofertilizers were not significant $(\mathrm{P}>0.01)$ and there is no interaction between biofertilizers and rates and biofertilizer and cutting period on evaluated parameters of B. brizantha cv. Piatã. Thus, it can be considered that once the biofertilizers produced from cattle and swine are applied in a proper manner (by correcting the level of nitrogen according to its level content in each fertilizer), there is no difference in the nutrient intake, which provides a similar growth rate for the plants. Scheffer-Basso et al. (2008) compared fertilized pastures with cattle and swine manure and pointed out that the best results were found with swine manure, probably due to higher level of nitrogen and phosphorous content. However, the authors only compared the levels in $\mathrm{m}^{3}$.ha $\mathrm{a}^{-1}$ and did not take into account the water content (solid content) and amount of nutrients kept on the effluents which influences the amount of nutrient applied on the area. The comparison between effluents is more precise when the effluents are evaluated in similar conditions, although differences were not observed on growth of the plants according to the type of biofertilizer in this study.

With regard to the different rates of biofertilizer, the productions of green matter and dry matter were significant ( $\mathrm{P}<0.01$ ) with the increasing of nitrogen rate, according to a linear prediction model (Figure 1).

Table 3 - Cutting intervals (days) in regard to nitrogen rate and different cutting periods of Brachiaria brizantha cv. Piatã

\begin{tabular}{ccccc}
\hline Rate $(\mathrm{kg} \mathrm{N}$ N.ha & \\
& \multicolumn{4}{c}{ Period } \\
\cline { 2 - 5 } & $1^{\text {st }}$ cut & $2^{\text {nd }}$ cut & $3^{\text {rd }}$ cut & $4^{\text {th }}$ cut \\
\hline 0 & 20 & 24 & 28 & 35 \\
100 & 18 & 21 & 22 & 31 \\
200 & 14 & 18 & 21 & 30 \\
300 & 13 & 15 & 16 & 26 \\
\hline
\end{tabular}


The productions of green and dry matter, respectively, 192 and $113 \%$ were greater in the treatment with $300 \mathrm{~kg} \mathrm{~N} . h a^{-1}$ than when compared with the control treatment. Also Barnabé (2001) compared the control treatment (without fertilizer) and the maximum rate of swine lagoon effluent and observed an increase of $156 \%$ on the dry matter production of $B$. brizantha cv. Marandu pasture. The author found a linear relation between the production of dry matter and levels of swine lagoon effluent.

Analyzing the structural and morphogenetic features, the influence of the $\mathrm{N}$ levels on these studied variables could be observed, $(\mathrm{P}<0.01)$, also fitting a linear prediction model (Figure 2).

The findings presented in the literature about the behavior of structural and morphogenetic variables are varied with respect to different levels of nitrogen. Alexandrino et al. (2004) found a linear relation between the structural and morphogenetic characteristics of $B$. brizantha $\mathrm{cv}$. Marandu according to the levels, 0, 20 and 40 mg N.dm ${ }^{3}$.week ${ }^{-1}$. However, Silva et al. (2009) estimated a quadratic model for the same species and variables.

The reason for such variation may be related to the period of the year when the experiment was carried out, also due to fertility of the soil (residual amount of nutrients) and type of pot used (a drilled one does not prevent the leaching of nutrients). Another aspect that must be taken into account is the range in which the data are evaluated; therefore, the higher levels of nitrogen are applied on the pots, the greater the chance of quadratic behavior occurring, as reported by Silva et al. (2009), who used a range of evaluation up to $380 \mathrm{~kg} \mathrm{~N} . \mathrm{ha}^{-1}$, i.e., the level was $80 \mathrm{~kg} \mathrm{~N} . \mathrm{ha}^{-1}$ superior to that one used in this study, so it was possible to find the peak of grass growth.

According to MacAdam et al. (1989) the increase in LER along with the increase of nitrogen levels is due to the improvement of cell production (cell division), without effect on the final size of the cell or on the cell epidermal

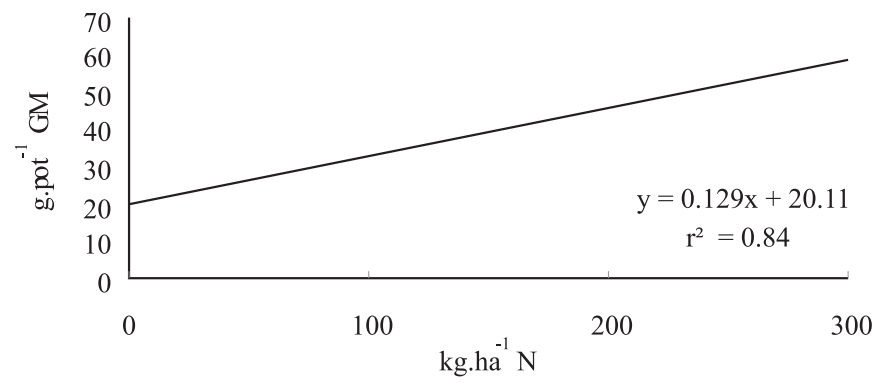

Statistical significance level at $1 \%$. elongation rate. An increment of $55.15 \%$ in the leaf elongation was observed in the plants that received the highest level of nitrogen in comparison with those that were not fertilized. This gain is responsible, in part, for the increase in the dry matter production (Figure 1), which is linked to the enlargement of the leaf area, and probably for the best ratio between carbon and nitrogen for the plants regrowth (Alexandrino et al., 2004). The leaf elongation rate is related to the dry matter yield, as reported by Gomide (1997), which, in turn, explains great part of the amount of produced forage.

The LAR increased from 0.14 to 0.17 leaf.tiller ${ }^{-1}$. day ${ }^{-1}$ for the plants that received the highest $\mathrm{N}$ rate when compared to the non-fertilized. Lemaire \& Chapman (1996) stated that the LAR plays a central role in morphogenesis, because it influences directly on each of the three components of the structure of the pasture. There is a close relation between the LAR and tiller density, which determines the potential for tillering of each genotype, once an emerged leaf potentially represents the emergence of a new tiller, i.e., the appearance of new axillary shoots. Consequently, if new tillers are developed, it is expected that high levels of $\mathrm{N}$ promote greater DM, because there is an increase in leaf area index of the pasture (Figure 1).

Thus, the increment in LAR led to a greater potential for emergence of tillers (Figure 2), so the tiller number and weight of the tiller were increased in about 4.5 and $70 \%$, respectively. Alexandrino et al. (2004) also observed a rise in tillering and tiller weight of $B$. brizantha cv. Marandu when the level of nitrogen was raised. Silva et al. (2009) observed a greater number of tillers per plant (12.8 tillers) at a level of $179 \mathrm{mg} \mathrm{N} \cdot \mathrm{dm}^{-3}$. According to the authors, the gain in the number of tillers per plant provides greater ground covering by the grass plant, which contributes to the reduction of land degradation due to lower exposure to the impact of rain and sun radiation.

The phyllochron is defined as the time spent for the emergence of a new leaf that is the inverse of LAR. Thus,

Figure 1 - Production of green matter (GM) and dry matter (DM) of Brachiaria brizantha cv. Piatã at different nitrogen rates. 

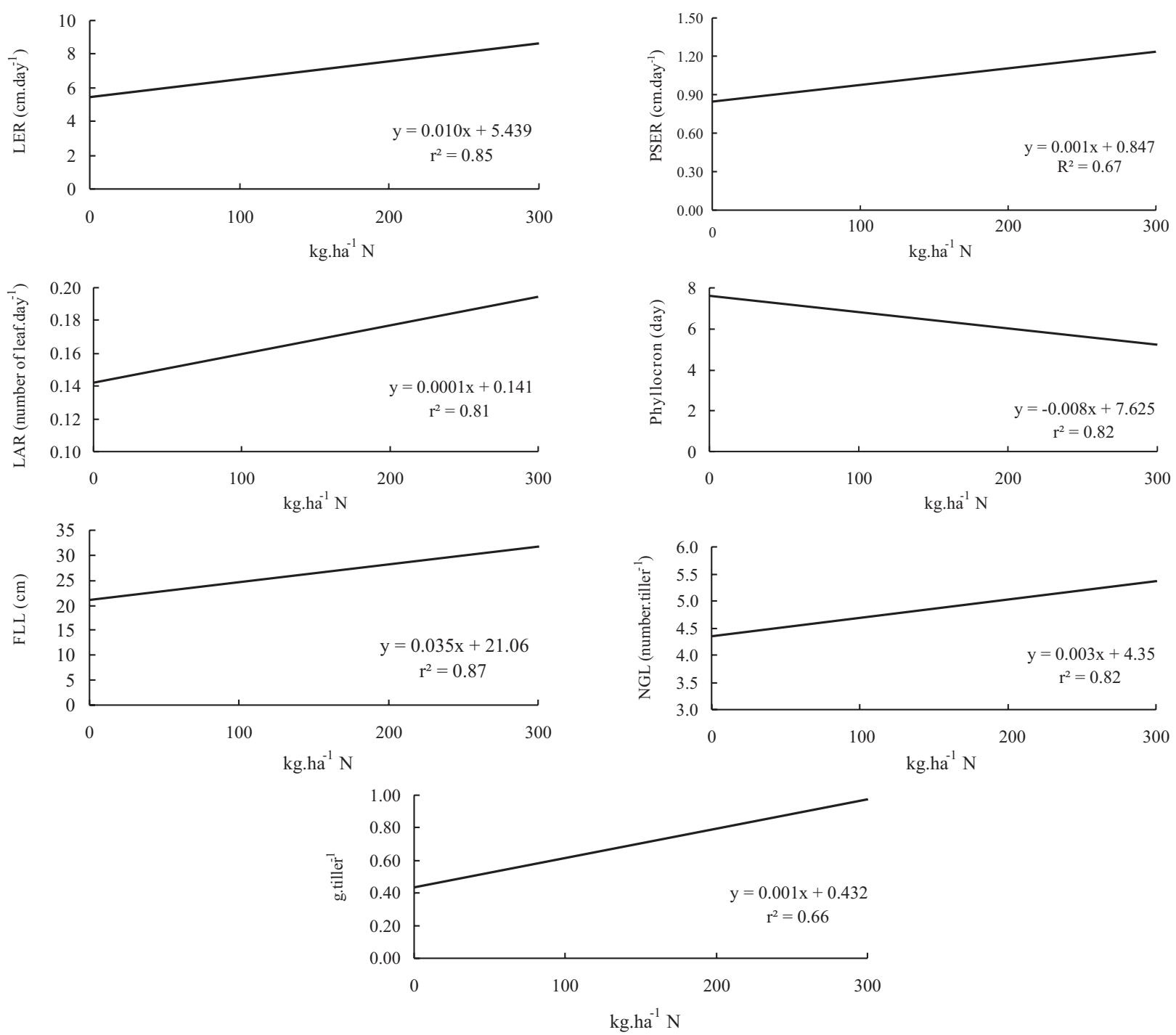

Statistical significance level at $1 \%$.

Figure 2 - Leaf elongation rate (LER), pseudostem elongation rate(PSER), leaf appearance rate(LAR), phyllocron, final leaf lenght (FLL), number of green leaves per tiller (NGL), number of tillers per pot and average weight of live tiller per pot of Brachiaria brizantha cv. Piatã at different nitrogen rates.

decrease in phyllochron value from 7.84 to 5.37 days at levels of 0 and $300 \mathrm{~kg} \mathrm{~N}^{-1}$ was observed, respectively. Alexandrino et al. (2004) evaluated the phyllochron in $B$. brizantha $\mathrm{cv}$. Marandu and reported that the increase of nitrogen rates reduced the phyllochron from 12.20 to 6.99 days in plants fertilized with 0 to $40 \mathrm{mg} \mathrm{N} \mathrm{dm}{ }^{-3}$. week $^{-1}$, respectively. Also, Martuscello et al. (2005) found phyllochron values for $B$. brizantha $\mathrm{cv}$. Xaraés of 11.45 and 8.81 days without fertilizer and with $120 \mathrm{mg}$. $\mathrm{N} \mathrm{dm}^{-3}$, respectively.

The relation of the number of tiller.pot ${ }^{-1}$ followed the equation: $y=0.002 x+13.13$, with $\mathrm{r}^{2}=0.33$. The low coefficient of determination of the model may be related to the limited space (pot experiment), which is a key point in the tillering of the plant.
There was effect on the yield characteristics and the tillering $(\mathrm{P}<0.1)$ (Table 4).

Although the first two cuts were performed during the summer season, the third cut (in autumn) presented the highest production of green and dry matter, a greater number of live tillers and heavier tillers. The reason is the first two cuts were made in a short time span and with fewer tillers, which ended up reflecting the amount of produced biomass and the number of dead tillers. The population of dead tillers was observed only during the third cut that occurred in April, which agrees with Moreira et al. (2009) who observed a rise in the number of dead tillers in April in the first year and in March and April in the second year. According to the authors, from April on, the demographics of live tillers on pasture may decrease as a result of an 
Table 4 - Production of dry matter and green matter and tillering of Brachiaria brizantha cv Piatã during different cutting periods

\begin{tabular}{|c|c|c|c|c|c|}
\hline \multirow[t]{2}{*}{ Yield characteristics } & \multicolumn{4}{|c|}{ Period } & \multirow[t]{2}{*}{$\mathrm{CV} \%$} \\
\hline & $1^{\text {st }}$ cut & $2^{\text {nd }}$ cut & $3^{\text {rd }}$ cut & $4^{\text {th }}$ cut & \\
\hline Green matter (g.pot ${ }^{-1}$ ) & $28.04 \mathrm{~b}$ & $32.62 b$ & $59.34 \mathrm{a}$ & $38.01 \mathrm{~b}$ & 17.45 \\
\hline \multirow[t]{2}{*}{ Tillering } & \multicolumn{4}{|c|}{ Period } & $\mathrm{CV} \%$ \\
\hline & $1^{\text {st }} \mathrm{cut}$ & $2^{\text {nd }}$ cut & $3^{\text {rd }}$ cut & $4^{\text {th }}$ cut & \\
\hline Live tillers.pot ${ }^{-1}$ & $8.45 \mathrm{~b}$ & $13.45 a$ & $14.41 \mathrm{a}$ & $14.41 \mathrm{a}$ & 13.98 \\
\hline
\end{tabular}

Mean values with distinct letters on the row are significant by the Scott-Knott test at $1 \%$ probability.

increased number of dead tillers and stabilization of the number of live tillers.

The effect of the cutting period was observed on the structural and morphogenetic characteristics of Piatã grass $(\mathrm{P}<0.01)$ (Table 5).

The first cut was the one with the highest values of LER, LAR, PSER, FLL, NGL and the lowest phyllochron values. In addition, these values decreased with the ending of the summer and beginning of the autumn. According to Euclides et al. (2008), this pattern of variation is typical of tropical regions as a result of the seasonality of rainfall, temperature and photoperiod, as in the specific case of this experiment, where there was the influence of temperature and photoperiod (Table 1) because soil moisture was under control throughout the experimental period.

There was a reduction of 35.64 and $26.31 \%$ in LER and LAR respectively, in comparison with the first and last cut. Barbosa (2004) observed higher values of LER and LAR during the summer and consequently higher values of phyllochron during the winter. According to Gastal et al. (1992), the leaf appearance and elongation rates are increased along with the rising temperature of the environment, influencing the final size of the leaf. The final size of the leaf is determined by the ratio of elongation rate/ appearance rate and also rises along with the increase of temperature, leading to the larger size of the leaves in the summer compared with other seasons. This pattern was also observed in this experiment, in which the leaves had an average of $30.69 \mathrm{~cm}$ in length for the first cut and $24.34 \mathrm{~cm}$ in the final cut.

Statistically significant differences $(\mathrm{P}<0.01)$ between the different periods of cutting were found for the NGL. In addition, the reduction in NGL was observed when comparing the cuttings performed during the summer and the autumn (Table 5). The NGL is a variable that is determined genetically, and each species or cultivar maintains the NGL regardless of the management. However, limitations of temperature and photoperiod promote its reduction, once the LAR that also determines NGL is decreased (Hodgson, 1990).

The PSER was also influenced over the cuttings like the other characteristics evaluated. The PSER is an important feature observed in tropical grasses of erect growth habit, which significantly influences the structure of the forage canopy and the process of competition for light (Sbrissia \& Silva, 2003). This variable is influenced by the elongation rate and elongation duration of each leaf, which means, the longer the duration of the phyllochron, the lower the PSER (Table 5). This relation was observed in this experiment, once the values of PSER were 1.79 and $0.72 \mathrm{~cm}_{\text {.tiller }}{ }^{-1}$. day ${ }^{-1}$ for the first and forth cuts which presented the smallest and largest phyllochron, respectively.

The findings of this study demonstrate the feasibility of using biofertilizers from swine and cattle manure on the Piatã grass, mainly because these results are in a similar range to those found in the literature using the mineral fertilizer. However, further research is needed in order to

Table 5 - Structural and morphogenetic characteristics of Brachiaria brizantha cv. Piatã during different periods of cut

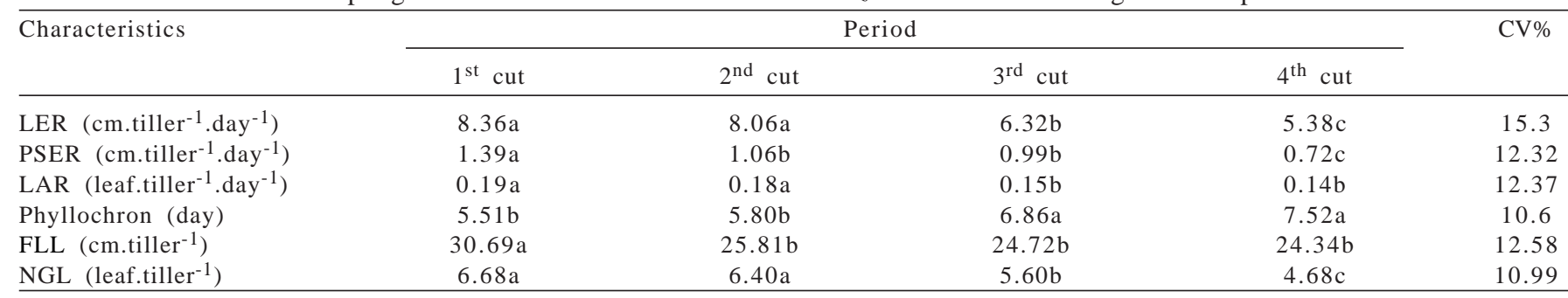

Mean values with distinct letters on the row are significant by Scott-Knott test at $1 \%$ probability.

LER - leaf elongation rate; PSER - pseudostem elongation rate; LAR - leaf appearance rate; FLL - final leag length; NGL - number of green leaves per tiller. 
evaluate other types of biofertilizers on other forage species. So, it will be possible to more precisely determine the fertilizer potential of the wastes from animal farm operations at forage production.

\section{Conclusions}

The structural, morphogenetic and productive characteristics of Brachiaria brizantha cv. Piatã respond increasingly up to the level of $300 \mathrm{~kg} \mathrm{~N} . \mathrm{ha}^{-1}$, regardless of the biofertilizer source used (cattle or swine manure).

\section{References}

ALEXANDRINO, E.; NASCIMENTO JÚNIOR, D.; MOSQUIM, P.R. et al. Características morfogênicas e estruturais na rebrotação da Brachiaria brizantha cv. Marandu submetida a três doses de nitrogênio. Revista Brasileira de Zootecnia, v.33, n.6, p.1372-1379, 2004.

AMERICAN PUBLIC HEALTH ASSOCIATION - APHA. Standard methods for examination of water and wastewater. 21.ed. Washington: American Water Works Association, 2005. 1368p.

BARBOSA, R.A. Características morfofisiológicas e acúmulo de forragem em capim-Tanzânia (Panicum maximum Jacq. cv. Tanzânia) submetido a freqüências e intensidades de pastejo. 2004. 116f. Tese (Doutorado em Zootecnia) - Universidade Federal de Viçosa, Viçosa, MG.

BARnABÉ, M. C. Produção e composição bromatológica da Brachiaria brizantha cv. Marandu adubada com dejetos líquidos de suínos. 2001. 67f. Dissertação (Mestrado em Ciência Animal) - Universidade Federal de Goiás, Goiânia.

EMPRESA BRASILEIRA DE PESQUISA AGROPECUÁRIA EMBRAPA. Sistema brasileiro de classificação de solos. Brasília: Embrapa, 1999. 412p.

EUCLIDES, V.P.B.; MACEDO, M.C.M.; VALLE,C. B. et al. Produção de forragem e características da estrutura do dossel de cultivares de Brachiaria brizantha sob pastejo. Pesquisa Agropecuária Brasileira, v.43, n.12, p.1805-1812, 2008.

GASTAL, F.; BÉLANGER, G.; LEMAIRE, G. A model of the leaf extension rate of tall fescue in response to nitrogen and temperature. Annals of Botany, v.70, p.437-442, 1992.

GOMIDE, J.A. Morfogênese e análise de crescimento de gramíneas tropicais. In: SIMPÓSIO INTERNACIONAL SOBRE PRODUÇÃO ANIMAL EM PASTEJO, 1., 1997, Viçosa, MG. Anais... Viçosa, MG: Universidade Federal de Viçosa, [1997]. (CD-ROM)
HODGSON, J. Grazing management: Science into practice. 3.ed. New York: John Wiley \& Sons, 1990. 203p.

LEMAIRE, G.; CHAPMAN, D. Tissue flows in grazed plant communities. In: HODGSON, J.; ILLIUS, A.W. (Eds.). The ecology and management of grazing systems. [S.l.]: Cab International, 1996. p.03-36.

MacADAM, J.W.; VOLENEC, J.J.; NELSON, C.J. Effects of nitrogen on mesophyll cell division and epidermal cell elongation in tall fescue leaf blades. Plant Physiology, v.89, p.549-556, 1989.

MARTUSCELLO, J.A.; FONSECA, D.M.; NASCIMENTO JÚNIOR, D. et al. Características morfogênicas e estruturais do capimxaraés submetido à adubação nitrogenada e desfolhação. Revista Brasileira de Zootecnia, v.34, n.5, p.1475-1482, 2005.

MOREIRA, L.M.; MARTUSCELLO, J.A.; FONSECA, D.M. et al. Perfilhamento, acúmulo de forragem e composição bromatológica do capim-braquiária adubado com nitrogênio. Revista Brasileira de Zootecnia, v.38, n.9, p.1675-1684, 2009.

OLIVEIRA, W. Uso da água residuária de suinocultura em pastagem de Brachiaria decumbens e grama estrela Cynodon plesctostachyum. 2006. 104f. Dissertação (Mestrado em Agronomia)-Escola Superior de Agricultura "Luiz de Queiroz"/Universidade de São Paulo Piracicaba.

PEDREIRA, B.C.; PEDREIRA, C.G.S.; DA SILVA, S.C. Estrutura do dossel e acúmulo de forragem de Brachiaria brizantha cultivar Xaraés em resposta a estratégias de pastejo. Pesquisa Agropecuária Brasileira, v.42, n.2, p.281-287, 2007.

SBRISSIA, A.F.; DA SILVA, S.C.; MATTHEW, C. et al. Tiller size/ density compensation in grazed Tifton 85 bermudagrass swards. Pesquisa Agropecuária Brasileira, v.38, n.12, p.1459-1468, 2003.

SCHEFFER-BASSO, S.M., SCHERER, C.V., ELLWANGER, M.F. Resposta de pastagens perenes à adubação com chorume suíno: pastagem natural Revista Brasileira de Zootecnia, v.37, n.2, p.221-227, 2008

SILVA, A.A.; COSTA, A.M.; XAVIER, C.A.N. et al. Efeito da aplicação de dejetos líquidos de suínos e fertilizantes minerais na absorção de nutrientes em pastagem de Brachiaria decumbens. In: ENCONTRO LATINO AMERICANO DE INICIAÇÃO CIENTÍfICA, 10., 2006, São José dos Campos. Anais... São Paulo: Universidade do Vale do Paraíba, [2006], (CD-ROM).

SILVA, C.C.F.; BONOMO, P.; PIRES, A.J.V. et al. Características morfogênicas e estruturais de duas espécies de Braquiária adubadas com diferentes doses de nitrogênio. Revista Brasileira de Zootecnia, v.38, n.4, p.657-661, 2009.

SILVA, D.J.; QUEIROZ, A.C. Análise de alimentos: métodos químicos e biológicos. 3.ed. Viçosa, MG: Editora Universitária, 2006. 166p.

SILVEIRA, M.C.T.; NASCIMENTO JÚNIOR, D.; DA SILVA, S.C.; et al. Morphogenetic and structural comparative characterization of tropical forage grass cultivars under free growth. Scientia Agrícola, v.67, n.2, p.136-142, 2010. 